\title{
KOS HEART INFARCTION - WHERE ARE WE GOING?
}

Maciej Rogala', Piotr Buszman ${ }^{2,3}$, Ewa Donesch-Jeżo ${ }^{4}$, Anna Sagan ${ }^{5}$, Iwona Kowalska-Bobko ${ }^{1}$

1 DEPARTMENT OF HEALTH POLICY AND MANAGEMENT, INSTITUTE OF PUBLIC HEALTH, FACULTY OF HEALTH SCIENCES, JAGIELLONIAN UNIVERSITY, MEDICAL COLLEGE, KRAKOW, POLAND

2 CARDIOLOGY DEPARTMENT, ANDRZEJ FRYCZ MODRZEWSKI KRAKOW UNIVERSITY, BIELSKO-BIALA, POLAND

3 CENTER FOR CARDIOVASCULAR RESEARCH AND DEVELOPMENT OF AMERICAN HEART OF POLAND, KATOWICE, POLAND

4 FACULTY OF PSYCHOLOGY AND HUMANITIES, ANDRZEJ FRYCZ MODRZEWSKI KRAKOW UNIVERSITY, KRAKOW, POLAND

5 EUROPEAN OBSERVATORY ON HEALTH SYSTEMS AND POLICIES

\section{Abstract}

The introduction of a new patient care model after acute coronary syndrome (ACS) in Poland as part of the Comprehensive Patient Care Program after a Heart Attack (KOS) resulted in improved patient treatment quality and reduced mortality due to diseases of the cardiovascular system within 12 months after the onset of heart attack - these are the first results after two years of functioning of this model. The program has been operating since 0ctober 1, 2017, and was introduced to improve the care of patients after cardiovascular incidents and its main goal is to improve the quality of treatment and reduce patient mortality. The program has already been corrected due to limitations and problems reported by the cardiologists.
Key words

KOS-infarction,

acute coronary syndromes, invasive cardiology,

comprehensive and coordinated medical care,

reduction of cardiovascular risk

\section{INTRODUCTION}

There are currently 49 million patients with cardiovascular disease throughout Europe. In Poland, as in other European Union (EU) countries, cardiovascular disease is the leading cause of death, and in the EU about 1.8 million people die every year because of it [1-3]. In Poland, although mortality due to cardiovascular disease has been steadily decreasing since the beginning of the $90 \mathrm{~s}$, it is still high, as it remains close to $46 \%$ and is on average $8 \%$ higher than in other EU countries [4-7].

In the past over a dozen years, mainly in the period 2000-2014, there has been a significant increase in expenditure on cardiology from PLN 1 billion to PLN 3 billion in Poland, including invasive cardiology from PLN 200 million to PLN 1.2 billion. This led to an increase in patients' access to the network of hemodynamic laboratories operating on a 24-hour basis as a result of the creation of new centers for the intervention treatment of ACS in various regions of the country. While in 2004 there were 50 such centers, now their number has increased to 156 and coronary angioplasty performed in them led to a reduction in hospital mortality and early mortality after a cardiovascular incident. Experts emphasize that the model of ACS treatment developed over the past 20 years in invasive cardiology centers should be considered effective and, moreover, Poland has become one of the European leaders in this field [8-10].

On the other hand, it should be noted that the standardized coefficient of cardiovascular death rate is higher in our country than in most EU countries, and hospital mortality in the course of ACS treatment fluctuates around $10.5 \%$. In addition, $10.1 \%$ of patients die within 2 months after discharge [11]. The main causes of patient post-hospitalization mortality are, among others: inadequate lifestyle, insufficient monitoring of risk factors, delayed full revascularization, insufficient or delayed cardiac rehabilitation, suboptimal pharmacotherapy (interrupted or used irregularly), difficult and delayed access to subsequent angioplasty aimed at obtaining complete revascularization, implantation of cardioverter-defibrillators, as well as insufficient access to outpatient specialist care [11].

In order to change this situation, i.e. to improve the quality of treatment of patients and reduce mortality caused by cardiovascular diseases within 12 months after the onset of infarction, first a concept was created and then in October 2017 a new system of comprehensive and coordinated care for patients after ACS named in short KOS-infarction was introduced.

\section{DIAGNOSIS OF THE PROBLEM}

One of the main problems raised by the cardiologists were gaps in access to cardiac rehabilitation, which left the patient alone after leaving the hospital after heart attack, without professional care and supervision. On average, only $23 \%$ of patients after myocardial infarction underwent stationary and day ward rehabilitation - most often in Opolskie (53\%), Śląskie (39\%) and Lubelskie (32\%) Voivodeships, and the least often in Dolnośląskie (17\%), 
Wielkopolskie (16\%) and Mazowieckie (8\%) Voivodeship. Another problem was the delayed time of rehabilitation - it was appointed late after the discharge from the hospital; a similar situation was with access to cardiologist's consultations - they were rare and took place also late after the discharge from the hospital. For example, the data from the Silesian Cardiovascular Base show that the median time from discharge from hospital to the first cardiological consultation was 4 months before entering KOS and only $57 \%$ of patients after heart attack had a cardiological consultation based on a contract with the National Health Fund. Another 9\% of patients had a consultation at private surgeries [11-13]. It should be noted, however, that the low percentage of patients entering rehabilitation and outpatient specialist care after heart attack is not only a problem in Poland but also occurs in others countries of Western Europe, the United States or Japan, where this percentage is similar or slightly higher [14]. According to the assessment of the Central Statistical Office (GUS), the lack of significant changes in the treatment and rehabilitation of heart attacks will increase the number of deaths from cardiovascular diseases and in 2050 it may reach even $51 \%$. In the expert reports, the aspect of money distribution was also raised, which shows that although the total costs of expenditure on cardiovascular diseases, e.g. in 2011 reached as much as PLN 42 billion, only $35 \%$ concerned direct costs related to treatment and pharmacotherapy, and in $65 \%$ they included indirect costs related to lost productivity due to premature mortality, early retirement or disability pension due to incapacity for work and being on sick leave. [15]

\section{ANALYSIS OF OPTIMAL SOLUTIONS}

Already in 2013, the Polish Society of Cardiology (PTK), in the published report entitled "The optimal model of comprehensive rehabilitation and secondary prevention" indicated that the introduction of a model of comprehensive rehabilitation and secondary prevention - assuming that it covers only $50 \%$ of patients - on the one hand, it would allow avoiding nearly 2,200 deaths a year, as well as over 15,000 cardiological hospitalizations, and on the other hand it would be highly cost-effective [16]. Three years later, in April 2016, the report of the Agency for Health Technology Assessment and Tariffs (AOTMiT) entitled "Comprehensive care after myocardial infarction" was completed, and in August of the same year the report of PTK and AOTMiT entitled "Coordinated care after myocardial infarction" appeared. In both documents, it was emphasized that the treatment of myocardial infarction does not end in the hospital, and in order to

improve its effectiveness it is necessary to continue medical care and improve the quality of secondary prevention of cardiovascular diseases, which would significantly reduce the cardiovascular risk in these people. Among the factors affecting long-term mortality rates - based on the results of many studies, both Polish and international - are lifestyle changes, increased control of risk factors as well as access to cardiac rehabilitation and specialist consultations, and continuation of hospital treatment in case of clinical indications [11-12].

Both the AOTMiT report and the PTK position have become the substantive basis for creating comprehensive model principles of patient care after heart attack, based on the recommendations of the European Society of Cardiology related to comprehensive secondary prevention and rehabilitation, education, as well as control of risk factors, the use of which inhibits the progression of the disease, and also contributes to the extension of life span and improvement of quality of life. In both documents, experts pointed out that the optimal model of integrated medical care should include patient monitoring for 12 months after discharge from the hospital and consist of four elements: invasive treatment (interventional cardiology, electrotherapy, cardiac surgery), comprehensive rehabilitation, cardiological education, and specialist cardiac care. The payer should sign contracts for its implementation with centers that have the ability to implement each of these modules. The basic assumption of the model was to ensure continuity of patient care for a year as part of coordinated care provided by the entity with which the contract for the implementation of the entire program will be signed, ensuring access to the above-mentioned services at an optimal time taking into account the clinical parameters of the patient. It has been assumed that the analysis of survival and risk of serious coronary incidents will be the main indicators enabling the assessment of the effectiveness of the coordinated care system [11-12].

Table 1. Four-component model of coordinated and comprehensive healthcare - KOS-infarction [11-12].

Interventional cardiology

(full revascularization)

Rehabilitation and cardiological education

\section{COMPREHENSIVE AND COORDINATED CARE AFTER HEART INFARCT:} FIRST STEPS KOS HEART INFARCT IN POLAND

On May 29, 2017, the ordinance of the President of the National Health Fund (NFZ) No. 38/2017/DSOZ was issued determining the conditions for making 
contracts related to hospital treatment within comprehensive care after myocardial infarction (KOS-infarction). It was followed by determining detailed conditions to be met by entities that may be included in the program allowing for the implementation of health services within hospital treatment; cardiac rehabilitation and specialist cardiological care [17].

The requirements to make the contract include the following [18]:

1. Formal requirements

a) having in the organizational structure: a hospital cardiology department,

b) possession in the organizational structure or on the basis of subcontracting or art. 132a of the Act on benefits: interventional radiology laboratory or hemodynamics laboratory and electrophysiology laboratory, hospital cardiosurgery ward, stationary cardiac rehabilitation ward or center or day cardiac rehabilitation ward, specialist cardiology outpatient clinic.

2. Requirements related to providing state benefits

a) the schedule for the provision of state benefits for coordinated care cannot limit the availability of services provided under other contracts,

b) 24-hour telephone contact (with the cardiology department) for patients under comprehensive care and the possibility to receive consultation for 24 hours.

3. Other conditions included coordination of all activities related to patient care within 12 months after the occurrence of myocardial infarction as described in KOS-infarction.

4. It was also assumed that comprehensive care would be coordinated by one center - a coordinating entity, i.e. a hospital with a cardiology department, which over a year maintains care of a patient after heart attack including treatment, rehabilitation, and monitoring of the therapeutic process. After completing the provision of services for KOS-infarction, the coordinating entity provides information to the POZ/AOS doctor about the services recommended to the patient.

KOS-infarction officially commenced work on October 1,2017 , but only some of the cardiology centers in Poland decided to take part in it immediately or in the following year. AOTMiT estimated that KOS will include about $38 \%$ of patients, but in the beginning, only about $8 \%$ of patients took part in it out of about 100,000 heart attacks that occur in Poland every year $[11,19]$.

According to NFZ data, in 2017, 40 centers participated in the program, and a year later - 50. Analyzing economic values in the form of funds for implementa- tion of this program, the total amount of contracts for its implementation in Poland in the first three months of 2017 amounted to nearly PLN 32.5 million while in 2018, nearly PLN 151.4 million. Both in the first and second year of operation (in 2017 and 2018) of the KOS-infarction, most funds were allocated by the National Health Fund to cardiological centers operating in the Śląskie Voivodeship - approximately PLN 18.7 million and approximately PLN 59.5 million, respectively. The least funds came to the Kujawsko-pomorskie Voivodeship just over PLN 70,000; the program did not start in 2017 in three voivodships: Malopolska, Lubuskie, Podlasie and Zachodniopomorskie, next year it was not implemented only in Świętokrzyskie Voivodeship. While in the fourth quarter of 2017 only 1949 patients were treated, between the first and the third quarter of 2018 there were 8422 patients. In the discussed period, the number of services has also changed: from 5403 to 40510 . Three centers that had the most patients in 2018 were: American Heart of Poland (AHP) S. A. (896), Prof. L. Gieca Górnośląskie Medical Centre of Silesian Medical University in Katowice (761) and the J. Paul II Independent Public Specialist Hospital in Zamość (634) [20].

The largest KOS-infarction operator in 2017 and 2018 was the American Heart of Poland (AHP), which implemented KOS-infarction from November 1, 2017, in three centers in Bielsko-Biała, Dąbrowa Górnicza, and Tychy. Patients were included in each of the four modules of KOS-infarction. Of a total of 2,086 patients admitted to AHP in November 2018, $55.9 \%$ (1168 people) were qualified for the KOSinfarction program. Among the admitted patients, infarcts with NSTEMI N = 685 (58.6\%) dominated and the remaining group were infarcts with STEMI $\mathrm{N}=$ $483(41.3 \%)$. During the program, 581 patients were submitted to coordinating visits, 435 - AOS visits and 405 - rehabilitation, including stationary rehabilitation $\mathrm{N}=254(62.7 \%)$ and day rehabilitation $\mathrm{N}=151$ (37.2\%). Based on the Kaplan-Meier estimation, the annual mortality rate after MI was $1.6 \%$. This result, taking into account the background of available registration and literature data is significantly better compared to patients not covered by the program [21].

The implementation of KOS-infarction allowed the AHP to evaluate the program in the context of its limitations. One of the main issues was that in the first year of operation of the program, it was possible to include only about $50 \%$ of patients in the KOS program. It resulted from the fact that patients with myocardial infarction brought by emergency teams to cardiology departments in AHP could only be qualified for KOSinfarction in units located in the network of hospitals. 
The program does not create such a possibility for units outside the network (only about $50 \%$ of the AHP laboratories are in the network of hospitals). Another reason was the inability to attend KOS-infarction for patients qualified for coronary artery bypass grafting $(\mathrm{CABG})$ and requiring valve repair, as well as patients transferred from another hospital. Another limitation was a large number of patients who refused to take part in the program $\mathrm{N}=313$ and $\mathrm{N}=75$ "no show", which resulted in a high $\mathrm{N}=388(33.2 \%)$. This mainly concerned patients who were unable to commute to outpatient daily rehabilitation for a month. It is also worth mentioning that after two years of operation of the program, AHP is still among the leaders of this program throughout the country and has so far covered a total of about 2,300 patients [21-22].

\section{WEAKNESSES AND LIMITATIONS OF THE PROGRAM}

The KOS-infarction program after less than six months of operation was evaluated in terms of strengths of cardiac centers implementing its modules, which were presented in March 2018 during the session "Organization of medical care for patients after myocardial infarction and stroke" as part of the Third Congress of Health Challenges [23-24]. A month later, on April 26, 2018, an ordinance draft of the President of the NFZ (Polish National Health Fund) was published, which was the result of a joint position of the clinicians involved in the organization of KOS-infarction and the opinions of experts from the Polish Society of Cardiology and the Polish Society of Rehabilitation. Regulation No. 10/2019/DSOZ, after a series of external consultations, appeared on February 1, 2019, and was the result of all collected problems and limitations, among which the following ones were indicated [19, 25-26]:

- the need to introduce explicit provisions regarding the early termination of KOS-infarction or the transfer of a patient to another center having a contract for the provision of these services,

- the lack of correction coefficient within cardiology for entities that are institutes, such as in the case of the implementation of a contract for hospital services,

- the need for gratification for entities with their own rehabilitation ward (similar to the situation with coronary artery bypass grafting in the cardiac surgery ward in the organizational structure),

- enabling the settlement of the correction coefficient at the time of issuing the certificate confirming the absence of cardiological contraindications to work,

- problems with the settlement of benefits from the catalog of benefits to sum up and the stay in the
Department of Anaesthesiology and Intensive Care,

- enabling implementation of all JGP related to electrotherapy under KOS-infarction.

\section{THE FIRST CHANGES IN KOS-INFARCTION TOWARDS OPTIMIZATION}

All these elements were included in the new ordinance, in particular the following ones [27-28]:

- a correction coefficient of 1.1 for cardiological services for entities that are institutes, equivalent to the coefficient in the case of realization of a contract for the provision of hospital cardiological services,

- a coefficient of 1.1 for benefits within the day care unit for cardiac rehabilitation in the organizational structure, when settling day care services,

- enabling the settlement of the correction coefficient at the time of issuing the certificate confirming the absence of cardiological contraindications to work,

- enabling all JGP related to electrotherapy to be implemented under the KOS-infarction by adding groups: E31 implantation/replacement of a single-chamber pacemaker, E32 implantation/replacement of a dual-chamber pacemaker, and E33 implantation/replacement of the system having cardiac resynchronization function (CRT),

- in addition to the modules, a division into treatment, rehabilitation and monitoring were introduced, and a separate accounting of coordinating and control visit was made possible.

One of the changes that was called for was to equalize the financial benefits associated with the implementation of the program for institutes and clinical hospitals. Earlier, hospitals implementing KOSinfarction had a higher contract value with NFZ by $15 \%$, and clinical centers and institutes only by $5 \%$, which meant that only a few decided to participate in this project [29].

All these elements have been added or corrected in order to improve KOS-infarction, looking at its organization and content seen from the perspective of both the centers implementing it and the patients themselves. At the end of September 2019, 59 cardiological centres in the country participated in the project [30].

It should also be emphasized that, despite the fact that the program has undergone some changes to improve its functioning, the most important and visible after the first year of its operation is a significant reduction in mortality in patients undergoing this program to about $2.6 \%$ and even $1.6 \%$ depending on the 
Table 2. Organization of KOS-infarction in three areas: treatment, rehabilitation and monitoring [27-28].

\section{TREATMENT includes:}

1) hospitalization of the patient due to heart infarct which involved:

a) invasive diagnosis of myocardial infarction (coronary angiography) or conservative treatment,

b) invasive treatment, including complete coronary revascularization or cardiac surgery (according to the patient's clinical condition): I-stage revascularization - during hospitalization for heart infarct,

II-stage revascularization, which can be performed at the first hospitalization for heart infarct or spread over two hospitalizations (the first one because of heart infarct and the second one planned hospitalization);

2) electrotherapy, including:

a) implantation/replacement of a single-chamber pacemaker,

b) implantation/replacement of a double-chamber pacemaker,

c) implantation/replacement of the system with cardiac resynchronization function (CRT),

d) implantation of a cardioverter-defibrillator (ICD) or

e) implantation of a cardioverter-defibrillator with resynchronization function (CRT-D) after assessing the patient's ejection fraction;

3) individual patient treatment plan established during hospitalization by a cardiologist together with a medical rehabilitation specialist, taking into account appropriate cardiac rehabilitation and visits to a cardiological outpatient clinic.

\section{REHABILITATION includes:}

1) cardiac rehabilitation or hybrid cardiological telerehabilitation implemented in stationary conditions, or

2) cardiological or hybrid cardiac telerehabilitation carried out in the center or day ward.

\section{MONITORING includes:}

1) coordinating (control) visit,

2) specialist cardiac care within 12 months from the occurrence of myocardial infarction in accordance with the individual treatment plan [including consultations concerning qualification for implantation of the total automatic cardioversion system or the defibrillation (ICD system) or else the cardiac resynchronization system with defibrillation function (CRT-D system) and a consultation monitoring implantable devices]; the number of consultations and their frequency should depend on the patient's clinical condition,

3) a specialist consultation ending the care under the KOS-infarction program.

center, which compared to the average level of annual mortality after heart attack of $10.5 \%$ before the introduction of this program can be considered a breakthrough [31].

After the changes introduced in February 2019, the KOS-infarction organization has been divided into three main areas: treatment, rehabilitation, monitoring. The details of each area are described in Table 2 [27-28].

\section{QUALITY OF BENEFITS: ABOVE ALL}

According to the new decree of the President of the National Health Fund, detailed quality parameters were determined for the assessment of the provision of benefits. It was assumed that the monitoring and evaluation of the program of comprehensive care for patients after myocardial infarction will include both indicators on the quality of patient care at the level of the center implementing the comprehensive care program and indicators on the effects of treatment. Therefore, the following parameters used to assess the effects of comprehensive care in patients after myocardial infarction after 12 months of its implementation were specified - based on reporting data by service providers to the NFZ IT system [28-29]:

1. percentage share of patients after myocardial infarction covered by KOS-infarction;

2. percentage of patients in whom the entire individualized care scheme was completed;

3. percentage of cardiovascular re-hospitalization;
4. percentage of patients who underwent coronary angioplasty as part of the second stage of revascularization;

5. percentage of patients implanted with an ICD cardioverter/defibrillator;

6. percentage of patients implanted with a CRT-D cardioverter/defibrillator;

7. percentage share of deaths after heart attack due to a cardiovascular episode in the period:

a) 6 months from the date of the occurrence of a heart attack,

b) 12 months after the occurrence of a heart attack.

The cardiologists' community estimates that the introduced changes will result in the participation of a greater number of cardiological centers, which will translate into a greater number of patients participating in the KOS-infarction program and, as a result, will reduce the number of consecutive infarctions in the same patients and ultimately the number of deaths [32]. From the point of view of the work of rescuers operating on a daily basis in the State Emergency Medical System it is an important message, because in the long run - which should be subjected to detailed analyzes - it should translate into a smaller number of calls for repeated heart attacks and other cardiovascular incidents in previously hospitalized patients with OZW due to the existing secondary prevention system in the form of KOS-infarction. 


\section{WHERE SHOULD WE AIM}

In addition to the undoubted successes of KOSinfarction whose concept and implementation have been honored with the award "Milest Steps in the treatment of heart attack" bestowed since 2012 by the Silesian Centre for Heart Diseases in Zabrze, which was given to four institutions:

Polish Society of Cardiology, Ministry of Health, Agency for Assessment of Health Technological and Tariff System and the National Health Fund for "creating assumptions and implementing Polish innovative program of coordinated care for patients with myocardial infarction" [33] - there remains one serious problem that has not been solved yet.

Currently about $20 \%$ of patients with myocardial infarction participate in the KOS-infarction program, but it should be remembered that access to it is still very unevenly spread between voivodships, which means that, e.g. in Śląsk, this accessibility is incomparably better (nearly $40 \%$ of patients covered) than in other voivodships, where it still operates only on very small scale. It seems that in this situation, the appeal of the cardiologists, including representatives of the authorities of the Polish Society of Cardiology, to include in the KOS-infarction ultimately all patients and not only patients treated within the network of hospitals is the most right and should be analyzed and assessed by policy makers. Additionally, the use of innovative solutions such as telerehabilitation, the use of dedicated mobile applications (e.g. AfterAMI, CorrieHealth) to coordinate patients should reduce the percentage of refusals to join the program for logistical and coordination reasons.

The sum of the benefits from this cannot be overestimated if we take into account that, above all, the rate of deaths from cardiovascular diseases in the country may decrease. The entire health care system will also benefit from the treatment of fewer subsequent heart attacks with a greater share of preventive measures that are more effective and cheaper than hospital treatment. Also, for rescuers working in PRM teams, this may result in fewer outpatient interventions to people who have had previous heart attack and then have been subjected to a comprehensive and coordinated secondary prevention program under the existing KOS-infarction program.

\section{CONCLUSIONS}

The 23rd International Congress of the Polish Society of Cardiology, which took place at the end of September 2019 in Katowice, gave an opportunity to summarize the two-year functioning of KOS myocardial infarction. In the conclusions drawn by representatives of the Polish Society of Cardiology, the Ministry of Health, NFZ, and AOTMiT, special attention should be paid to [34-35]:

1. The implementation of the KOS-infarction program meant that patients covered by this program can count not only on cardiac intervention related to ACS but also on comprehensive coordinated care including an individual treatment plan received by each patient for a period of 12 months after its occurrence, comprising both rehabilitation, consultation and further treatment according to the clinical condition.

2. The effects of treatment improved, as mortality within the year after hospitalization associated with myocardial infarction and the risk of further serious cardiovascular incidents significantly decreased. The data show that 12 -month mortality after heart attack dropped by 31 percent in the group of patients who were included in KOS-infarction, and the probability of serious cardiovascular events within 1 year is 25 percent lower than in the group of patients not included in the program.

3. On the one hand, the patients included in the program had increased availability of rehabilitation, and on the other hand, the time to start rehabilitation shortened as compared to patients after ACS not being in the KOS-infarction program. $67.1 \%$ of patients included in KOS-infarction had cardiac rehabilitation and the median time to start of rehabilitation was 11 days. For comparison, in patients not included in the programs, these two indicators were: 27.4 percent and 32 days.

\section{REFERENCES}

1. The European Heart Network (EHN). Heart Failure and Cardiovascular Diseases. URL: http://www.ehnheart.org/publications-and-papers/publications/1202:heart-failure-and-cardiovascular-diseases.html [Accessed: 23.09.2019]

2. Eurostat Statistics Explained. Cardiovascular diseases statistics. URL: https://ec.europa.eu/eurostat/statistics-explained/index.php/Cardiovascular_diseases_statistics\#Deaths_from_cardiovascular_diseases][Accessed: 23.09.2019]

3. The European Heart Network (EHN). European Cardiovascular Disease Statistics 2017. URL: http://www. ehnheart.org/cvd-statistics.html [Accessed: 23.09.2019] 
4. Kopeć G, Jankowski P, Pająk A, Drygas W. Epidemiology and prevention of cardiovascular diseases. Kraków: Medycyna Praktyczna; 2015: 41-55

5. State of Health in the EU: Country Health Profile 2017 - Poland. URL: https://ec.europa.eu/health/sites/ health/files/state/docs/chp_poland_english.pdf. [Accessed: 23.09.2019]

6. Kobza J, Geremek M. Explaining the Decrease in Deaths from Cardiovascular Disease in Poland. The Top-Down Risk Assessment Approach, from Policy to Health Impact. Postepy Hig Med Dosw (Online). 2016;70:295-304.

7. Eurostat Statistics Explained. Cardiovascular diseases statistics URL: https://ec.europa.eu/eurostat/statistics-explained/pdfscache/37359.pdf [Accessed: 24.09.2019]

8. Informacja o wynikach kontroli NIK. Realizacja świadczeń zdrowotnych z zakresu kardiologii przez publiczne i niepubliczne podmioty lecznicze. URL: https://www.nik.gov.pl/plik/id,10872,vp,13213.pdf [Accessed: 24.09.2019]

9. Rużyłło W, Gil RJ, Witkowski A. Zabiegi koronarografii i przezskórnej angioplastyki wieńcowej w Polsce w latach 1993-2004. Analiza z perspektywy przewodniczących Sekcji Kardiologii Inwazyjnej Polskiego Towarzystwa Kardiologicznego. Post Kardiol Int 2005;1: 3-7.

10. Baza pracowni Asocjacji Interwencji Sercowo Naczyniowych PTK URL: http://www.aisn.pl/pracownie/ baza_pracowni. [Accessed: 29.09.2019]

11. Raport AOTMiT. Opieka kompleksowa po zawale mięśnia sercowego. URL: http://www.aotm.gov.p1/ www/wp-content/uploads/2016/08/AOTMiT_WT_553_13_2015_OZW_kompleksowa_raport.pdf [Accessed: 29.09.2019]

12. Jankowski P, Gąsior M, Gierlotka M et al. Opieka koordynowana po zawale serca. Stanowisko Polskiego Towarzystwa Kardiologicznego oraz Agencji Oceny Technologii Medycznych i Taryfikacji. Kardiol. Pol. 2016;74: 395-406.

13. Kuta W. KOS-zawał - jak nam się udaje realizować ten program kompleksowej opieki? Rynek Zdrowia 15.03.2019 URL: http://www.rynekzdrowia.pl/Serwis-Kardiologia/KOS-zawal-jak-nam-sie-udajerealizowac-ten-program-kompleksowej-opieki,182240,1014.html [Accessed: 30.09.2019]

14. Turk-Adawi K, Sarrafzadegan N, Grace SL. Global Availability of Cardiac Rehabilitation. Nat Rev Cardiol. 2014;11(10):586-596.

15. Prognoza ludności na lata 2014-2050. GUS. Warszawa 2014. URL: https://stat.gov.p1/obszary-tematyczne/ludnosc/prognoza-ludnosci/prognoza-ludnosci-na-lata-2014-2050-opracowana-2014-r-,1,5.html [Accessed: 30.09 .2019$]$

16. Raport z prac zespołu ekspertów Polskiego Towarzystwa Kardiologicznego. Optymalny Model Kompleksowej Rehabilitacji i Wtórnej Prewencji. Warszawa 2013. URL: https://www.rehabilitacjakardiologicznaptk.pl/wp-content/uploads/2015/02/Optymalny_Model_RAPORT.pdf [Accessed: 30.09.2019]

17. Zarządzenie prezesa NFZ 38/2017/DSOZ w sprawie określenia warunków zawierania i realizacji umów $\mathrm{w}$ rodzaju leczenie szpitalne $\mathrm{z}$ zakresu kompleksowej opieki po zawale mięśnia sercowego (KOSzawał). URL: https://www.nfz.gov.pl/zarzadzenia-prezesa/zarzadzenia-prezesa-nfz/zarzadzenie-nr382017dsoz,6578.html [Accessed: 30.09.2019]

18. Warunki wymagane do zawarcia umowy. Załącznik do zarządzenia prezesa NFZ 38/2017/DSOZ. URL: https://www.nfz.gov.pl/zarzadzenia-prezesa/zarzadzenia-prezesa-nfz/zarzadzenie-nr-382017dsoz,6578. html [Accessed: 01.10.2019]

19. Gziut A. KOS-zawał — czas na zmiany? Kardiologia inwazyjna nr 3(15), rok 2018

20. Rutkowski. D. KOS zawał - leczenie zawału serca; perspektyw płatnika. (Departament Świadczeń Opieki Zdrowotnej Centrala NFZ). Wystąpienie konferencyjne 23-24.10.2018, Kardiologia Prewencyjna Kraków 2018

21. Buszman P. Wstępne wyniki chorych po zawale serca włączonych do programu KOS w American Heart of Poland. (Centrum Badawczo-Rozwojowe AHP) Wystąpienie konferencyjne 23-23.10.2018, Kardiologia Prewencyjna Kraków 2018

22. American Heart of Poland: dane potwierdzają, że KOS-zawał to olbrzymi sukces. ISB Zdrowie URL: https://www.isbzdrowie.p1/2019/09/american-heart-of-poland-dane-potwierdzaja-ze-kos-zawal-to-olbrzymi-sukces/ [Accessed: 01.1.0.2019]

23. Spotkanie Rady Naukowej HCC 2019 - relacja. URL: http://www.hccongress.pl/2019/pl/rada-naukowa/216/ [Accessed: 01.10.2019] 
24. Wojciech K. Będą zmiany w programie kompleksowej opieki nad pacjentami po zawale. Rynek Zdrowia. 16.03.2019. URL: http://www.rynekzdrowia.pl/Serwis-Kardiologia/Beda-zmiany-w-programiekompleksowej-opieki-nad-pacjentami-po-zawale,182268,1014.html [Accessed: 01.10.2019]

25. Kurowska A. Nowe zarządzenia NFZ m.in. o zmianach KOS-Zawał i opiece w ciąży. Polityka Zdrowotna 1.02.2019 URL: https:/www.politykazdrowotna.com/41009, nowe-zarzadzenia-nfz-min-o-zmianach-koszawal-i-opiece-w-ciazy [Accessed: 01.10.2019]

26. NFZ opublikował zarządzenie ws. umów leczenie szpitalne - świadczenia kompleksowe. Rynek Zdrowia 1.02.2019 http://www.rynekzdrowia.pl/Finanse-i-zarzadzanie/NFZ-opublikowal-zarzadzenie-ws-umowleczenie-szpitalne-swiadczenia-kompleksowe,191683,1.html [Accessed: 02.10.2019]

27. Zarządzenie Nr 10/2019/DSOZ z dnia 31 stycznia 2019 r. w sprawie warunków zawierania i realizacji umów w rodzaju leczenie szpitalne - świadczenia kompleksowe URL: https://nfz.gov.pl/zarzadzenia-prezesa/zarzadzenia-prezesa-nfz/zarzadzenie-nr-1332019dsoz,7030.html [Accessed: 02.10.2019]

28. Warunki wymagane do zawarcia umowy do załącznika do nowego zarządzania NFZ Nr 10/2019/DSOZ z dnia 31 stycznia 2019 r. URL: https://nfz.gov.pl/zarzadzenia-prezesa/zarzadzenia-prezesa-nfz/zarzadzenie-nr-1332019dsoz,7030.html [Accessed 02.10.2019]

29. Zmiany w KOS-zawał sprawią, że program obejmie więcej pacjentów. Puls Medycyny 01.03.2019. URL: https://pulsmedycyny.pl/zmiany-w-kos-zawal-sprawia-ze-program-obejmie-wiecej-pacjentow-954684 [Accessed: 02.10.2019]

30. Gumułka A. Szumowski: program “KOS-zawał” jest sukcesem. Medycyna Praktyczna URL: https://kardiologia.mp.pl/wiadomosci/217521,szumowski-program-kos-zawal-jest-sukcesem [Accessed: 05.10.2019]

31. Lurka K, Jankowski P. Śmiertelność wśród pacjentów objętych KOS-Zawał jest niska. Wynosi nawet 1,6 proc. Termedia URL: https://www.termedia.pl/mz/Piotr-Jankowski-Smiertelnosc-wsrod-pacjentowobjetych-KOS-Zawal-jest-niska-Wynosi-nawet-1-6-proc-,32374.html [Accessed: 05.10.2019]

32. Kardiolodzy: zmiany w programie KOS-Zawał pozwolą objąć nim więcej pacjentów. Rynek Zdrowia 1.03.2019. URL: http://www.rynekzdrowia.pl/Serwis-Kardiologia/Kardiolodzy-zmiany-w-programieKOS-Zawal-pozwola-objac-nim-wiecej-pacjentow,192528,1014.html [Accessed: 05.10.2019]

33. 4 instytucje z prestiżową nagrodą za KOS-Zawał. Medexpress 07.06.2019 URL: https://www.medexpress. pl/4-instytucje-z-prestizowa-nagroda-za-kos-zawal/73942 [Accessed: 05.10.2019]

34. Kurzyńska E. Efekty programu KOS-zawał: co wiemy po dwóch latach? Puls Medycyny 01.10.2019. URL: https://pulsmedycyny.pl/efekty-programu-kos-zawal-co-wiemy-po-dwoch-latach-971821 [Accessed: 06.10.2019]

35. KOS zawał to wielki sukces. Portale Medyczne 30.09.2019. URL: https://portalemedyczne.pl/index.php/ kos-zawal-to-wielki-sukces/ [Accessed: 06.10.2019]

\section{ORCID AND CONTRIBUTIONSHIP*}

Maciej Rogala - 0000-0001-8104-7617 A,B, , , D,E,F

Piotr Buszman - B, C, D, E, , F

Ewa Donesch-Jeżo - 0000-0002-4655-8822 D,E,F

Anna Sagan - 0000-0002-9304-8286 E,F

Iwona Kowalska-Bobko - 0000-0003-3728-2323 E

\section{CONFLICT OF INTEREST}

Authors declare no conflict of interest.

\section{ADDRESS FOR CORRESPONDENCE}

Maciej Rogala

Zakład Polityki Zdrowotnej i Zarządzania,

Instytut Zdrowia Publicznego,

Wydział Nauk o Zdrowiu,

Uniwersytet Jagielloński Collegium Medicum

ul. Grzegórzecka 20, Kraków, Poland

e-mail: maciej.rogala@uj.edu.pl
RECEIVED

13.10 .2019
ACCEPTED

10.12.2019

\footnotetext{
* Contribution: A - Work concept and design, B - Data collection and analysis, C - Responsibility for statistical analysis, D - Writing the article, E-Critical review, F- Final approval of the article.
} 